\title{
When Affirmative Action Disappears: Unexpected Patterns in Student Enrollments at Selective U.S. Institutions, 1990-2016
}

Discussions of U.S. affirmative action policy assume that considering race in undergraduate admissions increases Black and Latinx student enrollments. We show that this assumption accurately describes enrollment patterns for higher-status colleges and universities, but not institutions across the field of higher education. We use fixed effects modeling to analyze the association between a stated affirmative action admissions policy and enrollment trends for firstyear students of different racialized backgrounds between 1990 and 2016 at 1,127 selective institutions. We find that, at the most selective institutions, stated policy usage was associated with increased Black student enrollments. However, at less selective institutions, policy usage was associated with decreased Black enrollments and increased Non-U.S. resident enrollments. We also identify close-to-zero estimates of this relationship for enrollment trends of additional demographic backgrounds. We use these findings to elaborate the role of field-level status dynamics in racialized organizations theory. Paradoxically, U.S. American higher education's contemporary racialized status order roughly consists of higher-status institutions that consider race in admissions but do not enroll racially heterogenous cohorts, middle-status institutions that do not consider race but enroll racially heterogenous cohorts, and lower-status non-selective institutions that enroll disproportionately high numbers of Black, Indigenous, and Latinx students.

\author{
prabhdeep singh kehal \\ Brown University \\ prabhdeep_kehal@brown.edu \\ Daniel Hirschman \\ Brown University \\ daniel_hirschman@brown.edu
}

Ellen Berrey

University of Toronto

ellen.berrey@utoronto.ca

\section{Acknowledgments}

We thank Mikaila Mariel Lemonik Arthur, Jayanti Owens, and Emily Rauscher for comments on previous versions of this paper. Research funding was provided by Brown University's Program in Business, Entrepreneurship and Organizations. 
In July 2018, The Post and Courier reported that the College of Charleston, a predominantly White, selective, public university in South Carolina, had "quietly" eliminated its policy of considering race in admissions decisions (Bowers 2018a). The College's Vice President for Enrollment Management said the undergraduate admissions committee had decided it would stop "using race as a factor in the admissions process" because "student-of-color enrollments were increasing substantially" due to the college's diversity initiatives. Yet the College reversed its decision after outcry over the revealed policy change (Bowers 2018b). Media coverage noted the College's racialized enrollment trends but neglected a surprising pattern: enrollment levels of racially minoritized students were similar in the two years the College did not consider race and the previous years when it did. The policy did not seem to influence the College's enrollment patterns.

Tumult over the College's policy reveals a fundamental, taken-for-granted assumption in affirmative action debates in the United States: that considering applicants stated racial identity in admissions decisions uniformly increases Black and Latinx, and (when acknowledged) Indigenous, first-year enrollments. Elite universities and court decisions have reinforced this assumption. They justify affirmative action as necessary for boosting the enrollment of "underrepresented minority" students, particularly Black students, and achieving demographic "diversity" in the student body. While conservative activists contest the premise that proactively increasing Black enrollments is a legitimate goal (Okechukwu 2019), they have not challenged the assumption that considering race in admissions accomplishes that goal.

Major research studies have also reinforced this assumption. Both natural experiments and simulations firmly establish that elite institutions enroll more Black and Latinx students when they consider race compared to when they do not (Long and Bateman 2020; Reardon et al. 2018). 
However, these findings may not generalize beyond elite institutions. Student enrollments are highly stratified by racialized background according to an institution's position within U.S. higher education's pronounced status hierarchy (Posselt et al. 2012), and affirmative action's effects likely differ as well. By our calculations, the average percentage of Black students in first-year cohorts in 2016 was substantially lower at the most selective institutions than at less selective institutions, regardless of whether the institutions had a stated admissions policy of considering race (see Table 1). These calculations also show that, on average, Very Competitive and Competitive institutions that claim to consider race enroll fewer Black and Latinx students than those that do not. Additionally, two studies find dramatic declines in institutions' use of such policies, especially at institutions outside the highest prestige-tier (Grodsky and Kalogrides 2008; Hirschman and Berrey 2017).

To clarify the relationship between an admissions policy of considering race and first-year student enrollment demographics, we examine selective colleges and universities that can lawfully consider race in admissions. We ask: how do first-year student enrollments by racialized background differ according to an institution's policy of considering race or not? How do these relationships vary by institutions' status? Using data from the College Board's Annual Survey of Colleges (ASC), Integrated Postsecondary Education Data System (IPEDS), Barron's Profile of American Colleges (Barron's), and U.S. Census, we analyze the 1,127 four-year, public and notfor-profit private colleges and universities with first-year enrollment data from 1990-2016 and a Barron's ranking. Our two main independent variables are stated consideration of race (based on an ASC question) and status (measured by Barron's ranking of the competitiveness of their admissions process). We recategorize these competitiveness rankings as Maximally Competitive (the "higher-status" tier), Very Competitive, Competitive, and Less Competitive (together, a 
"middle-status" tier). Open enrollment institutions are not in our analysis but are generally considered the "lower-status" tier (Desilver 2019; McMillan Cottom 2017). Our dependent variables are the fall enrollment percentages of first-year students, according to their racial selfidentification-Black, White, Indigenous, Asian and Pacific Islander (API), Latinx - and residency - i.e., Non-U.S. resident students, whose U.S. racial identity is not available. Using fixed-effect modeling, we take advantage of the fact that many institutions changed their policy year-to-year to assess the relationship between average changes in first-year student enrollment demographics between 1990 and 2016 and institutions' stated admissions policies. We highlight Black student enrollments both because of the centrality of Black students to the origins and ongoing understood purpose of affirmative action policy and because of the distinctive dynamics revealed in our analysis.

We find that considering race in admissions does not have a unidirectional relationship with first-year enrollments by racialized backgrounds. We show that this relationship varies systematically across the status hierarchy of selective higher education. At Maximally Competitive institutions, the percentage of enrolled Black students was approximately 0.8 percentage points higher, on average, in years when those institutions stated policy usage compared to years in which they did not. Surprisingly, this pattern was reversed at Competitive and Less Competitive institutions, where the policy was associated with, on average, lower Black first-year student enrollments (approximately 0.6 and 2.0 percentage points, respectively), and higher average enrollments of Non-U.S. resident first-year students (approximately 0.4 and 0.5 percentage points, respectively). Our findings also identify many close-to-zero estimates for the policy's relationship with White, Latinx, and Indigenous first-year enrollments. These findings disrupt long standing, 
elite-centered assumptions around affirmative action admissions and Black student enrollments and call for greater attention to how organizations use the policy.

We use these empirical insights to elaborate existing theories of racialized organizations. We conceptualize racialized organizational policy in relation to field-level dynamics and by drawing on middle-status conformity theory, informed by analysis of meaning-making around policy. We argue organizations' stated use of racially-inclusive policy may be a constitutive element of a field's racialized status order without realizing the policy's original goal. As an explicitly racialized policy, affirmative action admissions has been linked-through cultural assumptions, statistical evidence, and court cases - to greater Black student enrollments at highly selective, predominantly White institutions, and it remains an institutional centerpiece of an elitecentered diversity imperative, despite successful conservative opposition. This context creates pressures on middle-status institutions to adopt similar policies despite having different student body demographics and admissions practices. Yet, we argue, differences in the demographics and practices across racialized organizations may lead to a racialized policy having minimal or counterintuitive effects in some parts of the field. Our findings indicate that stated use of racialized policy has different implications for racism depending on organizations' position in their field's status order: it can insulate high-status, white-dominated organizations from critique while enabling middle-status organizations to signal, but not substantiate, their compliance.

\section{RACIALIZED POLICY AND ORGANIZATIONAL FIELDS}

Theories of racialized organizations illuminate the organizational practices and mechanisms by which organizations, as meso-level structures that produce and allocate resources, maintain and, less often, challenge, racialized hierarchies (Ray 2019; Wooten 2006). We extend the theory of racialized organizations by conceptualizing racialized organizational policies in 
relation to field-level dynamics and by using middle-status conformity theory to explain the adoption, implementation, and abandonment of racialized policies. Elites and the public alike commonly understand policies like affirmative action in overtly racialized terms—-what we refer to as "racialized policy"-and consider them racially progressive, regardless of their actual efficacy (Fields and Fields 2012). We draw on the sociology of race, organizations, and culture to understand how such racialization of policy rests on assumptions about the policy's racialized consequences.

From neoinstitutional scholarship, we expect organizations' adoption, implementation, and abandonment of racialized policy is strongly influenced by field-level dynamics (Scott 2014). Field-level norms are established by higher-status organizations, and policy adoption by elite organizations commonly creates normative pressures for others to follow suit. Similarly, elite organizations' interpretations of racialized policy, such as their policy rationales and understandings of a policy's outcomes, can impact interpretations across the field. Middle-status conformity theory identifies specific pressures that lead middle-status organizations to conform to normative field-level practices and interpretations: these organizations risk losing their status if they flout the field's normative order, but they lack sufficient status to legitimate novel practices (Phillips and Zuckerman 2001). At the same time, it is reasonable to expect that elite-led practices and understandings, including those that are specifically racialized, might not be a good fit for middle- and lower-status organizations.

These field-level dynamics are necessary for interpreting racialized policy in higher education. The U.S. post-secondary status hierarchy is pronounced and historic, and practices and norms at "the top," including a "diversity imperative" (Stevens and Roksa 2011), are influential across the field, even though the majority of institutions are non-selective and many are less 
selective. For example, when faced with a state-imposed diversity mandate that was modeled on predominantly White public universities' racism-evasive policies, administrators at one $\mathrm{HBCU}$ (Historically Black College or University) developed a definition of diversity that would bring the institution into compliance with the field's diversity norms while limiting the mandate's impact on the representation of Black undergraduates (Carter 2015).

Sociological scholarship on race, organizations, and culture explains the organizational processes by which policies become racialized and perceived as consequential. Since the 1960s, political and organizational elites have advocated top-down, reformist laws and policies (e.g., from anti-discrimination to affirmative action to police body cameras legislation), in response to Black political uprisings pressuring the U.S. government and private sector to address deeply institutionalized racialized domination and segregation (Fields and Fields 2012). Through a process of tethering (Berrey 2015:273), organizational, political, and legal actors formulate cultural and pragmatic understandings of a policy. This tethering of cultural meaning to policy creates strong, patterned meanings around racialized policy that organizations and movements use to link policies to particular conceptions of racial progress and racialized outcomes. Tethering operates in conjunction with racialized decoupling, by which organizational actors de-link policies aimed at reducing racial inequality from practices that would achieve those outcomes (Ray 2019). Together, the two concepts explain how many organizational actors treat organizational diversity policy: explicitly understanding (and defending) the policy as one that reduces racial domination or exclusion, while simultaneously failing to implement the policy in ways that realize its promises.

Bridging these insights with theories of racialized organizations, we argue that racialized policies created for and promoted by higher-status organizations can be constitutive elements of 
the field's racialized status order while failing to substantially reduce racial inequality in higher education. The next section explains how affirmative action in higher education historically emerged and diffused and foregrounds field-level dynamics and the cultural tethering of the policy to Black student enrollments.

\section{FIELD PRESSURES ON AFFIRMATIVE ACTION ADMISSIONS POLICY}

\section{Adopting Affirmative Action to Increase Black Enrollment}

From its inception, elite, predominantly White institutions legitimated affirmative action in admissions as a means of boosting Black student enrollment. Administrators who first implemented affirmative action in the 1960s did so voluntarily in response to civil rights activists;

they adopted new policies that would enable them to admit small numbers of Black students without undermining their institution's prestige (Johnson 2020; Okechukwu 2019; Teddlie and Freeman 2002). In the 1970s, the federal government mandated that nineteen Southern public universities adopt affirmative action because they had violated court-ordered desegregation by failing to meaningfully enroll Black students (Shaw 2016; Teddlie and Freeman 2002). Widespread policy adoption followed. By the mid-1990s, at its peak, around $60 \%$ of selective institutions had a policy of considering race in admissions (Hirschman and Berrey 2017).

Considering applicants' demographic identity to increase Black students' higher education access was a departure from historic admissions policies. Aside from HBCUs and other explicitly segregated institutions, colleges and universities considered applicants' racialized identities to give preferential treatment to affluent, White, male, Christian, settler (i.e. non-Indigenous) students (Karabel 2005; Thelin 2004). When prompted to desegregate throughout the twentieth century, White universities routinely adapted their admissions practices to protect institutional interests tied to empowered, affluent, White constituencies (Anderson 1988; Karabel 2005; Thelin 2004), often 
in the form of formally race-neutral, but functionally discriminatory, admissions policies (Johnson 2020; Okechukwu 2019). These prevailing policies, which rarely are recognized as racialized, represent the deep entrenchment of many institutions' White supremacist origins: funded by slavery and built on (and still operating on) land taken from Indigenous nations (Harris 1993; Wilder 2013).

In contrast, affirmative action admissions seeks to increase the proportion of Black students on historically White campuses. Today, affirmative action can be incorporated into many admissions practices, such as recruitment and financial aid, but the policy is commonly conceived as intentionally considering applicants' racial identity as a factor in admissions decisions, separate from other academic and non-academic criteria. Supporters justify the policy in many ways: as partial reparations to reduce racialized inequality, as a means of counteracting biased admissions practices that fail to recognize Black students' merit, or as a method of ensuring that White students are exposed to educationally beneficial racialized diversity (see Berrey 2015). At the same time, opponents critique these policies as reverse racism serving Black students at the expense of (presumably more deserving) White students (see Johnson 2020; Okechukwu 2019). Despite their fundamental disagreements, supporters and opponents agree that affirmative action's objective has been to enroll more Black students and, to a lesser extent, Latinx and Indigenous students.

The broad-based adoption of affirmative action in postsecondary admissions can be explained, in large part, by the institutionalization of the elite-centric diversity imperative: the normative conviction that elite institutions should be academically excellent and racially heterogenous (Stevens and Roksa 2011). Since the late 1970s, administrators and admissions staff at elite institutions forged an association, both cultural and pragmatic, between affirmative action policy and the outcome of greater Black student enrollment (Lipson 2007). Elite universities' legal 
arguments and evidence asserted that affirmative action was essential for achieving the diversity imperative, and the U.S. Supreme Court validated this claim in major decisions (Berrey 2015). As the top-down diversity imperative became a field-level norm and affirmative action became tethered to diversity and Black student enrollment, less selective institutions faced pressures to mimic their higher status peers and adopted the policy.

\section{Conservative Opposition, Uneven Policy Abandonment, and Persistent Elite-Centered Interpretations}

White-led conservative pushback has undermined and compromised the use and purpose of affirmative action policy. Mobilized conservative opposition from the 1970s achieved major successes by the 1990s and continues in the present (Okechukwu 2019). Opponents argue that any deliberate consideration of race unfairly discriminates against White and (increasingly over the past decade) Asian American students (Okechukwu 2019). Their oppositional movement has discouraged and prevented many institutions from considering race in admissions and has helped to subvert the goal of increasing Black representation. With support from conservative judges and Republican-led government agencies, oppositional movement activists have challenged affirmative action's legitimacy and constitutionality, focusing on the most prestigious public institutions. Their lawsuits against prestigious public universities have yielded a series of Supreme Court decisions upholding the consideration of race in admissions but restricting its use. By 2012, their campaigns for state-wide bans resulted in eight states prohibiting public universities from considering race in admissions. State bans led to decreases in Black and Latinx student enrollments at the highest status public institutions (Bleemer 2020; Long and Bateman 2020).

Alongside this heightened political and legal scrutiny, the number of selective institutions with a stated admission policy of considering race declined in the 1990s. This decline proceeded 
unevenly across the field: higher-status institutions continued to consider race, but the policy was dropped by many middle-status institutions including private and public schools in states without bans (Hirschman and Berrey 2017). Our theoretical framework suggests that middle-status institutions' stated policy usage reflects the tradeoff between symbolically conforming to the elitecentric diversity norms tethered to affirmative action and the rising legal and political risks of using such policies.

Even with these documented declines, exactly how institutions consider race in decisionmaking is less clear. Admissions offices maintain a great deal of secrecy around how they do admissions; those that consider race rarely divulge specifics (Bastedo et al. 2018; Posselt 2016). Institutions tend to describe their policies in line with the Supreme Court's 2003 Grutter decision, which found that the only constitutional design of the policy was a highly individualized, holistic review of applications for the purposes of achieving student body diversity. The opacity makes it difficult to assess the extent to which contemporary policy is decoupled from admissions decisions and enrollment outcomes.

Nonetheless, popular understandings of the policy remain tethered to increased Black student enrollment. Even conservative activists have not challenged this association. Rather, they oppose the policy's goal of boosting Black enrollment, and they challenge the assertion that Black students benefit from affirmative action by making specious claims that the policy stigmatizes Black students (Brown-Nagin 2005) and channels them into universities where they are more

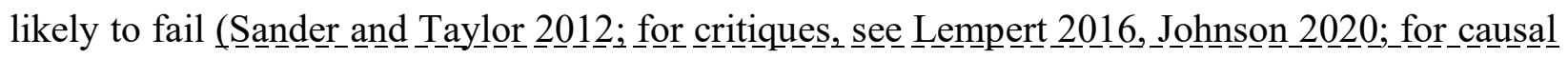
evidence inconsistent with mismatch theory, see Bleemer 2020). These field-level dynamics- - the varied use of this racialized policy across the status hierarchy and its entrenched cultural 
meanings - motivate our study's attention to the relationship between institutions' stated policy, institutional status, and enrollment trends.

\section{DATA AND METHODS}

We analyze the publicly declared admission policies of 1,127 institutions and their associations with first-year undergraduate enrollments between 1990 and 2016 by drawing on four data sources: the College Board's ASC, Barron's Profile of American Colleges, IPEDS, and the U.S. Census Bureau. The ASC collects annual survey data regarding institutional characteristics, including stated admissions policies, from more than 3,000 institutions. ASC data include all questions asked in the Common Data Set Initiative (www.commondataset.org), which is spearheaded by the College Board, Peterson's, and U.S. News \& World Report.

The ASC provides our primary independent variable: whether the institution reported that race was a factor in its admissions processes that year. After constructing our sample, missingness on this value was not systematic and was minimal, with $94-99 \%$ of institutions having a response in any year. Thus, our model included all institutions. Following existing scholarship, we generated a dichotomous measure for "considered race": institutions are given a " 1 " if they said they categorize Racial/Ethnic Status as a "Considered," "Important," or "Very Important" factor and a " 0 " if they did not consider it. This dichotomous treatment is justified both empirically and contextually. When we disaggregated institutions' answers to this question over time, responses varied primarily between whether race was "considered" or "not considered." When observing how much value was placed on considering race in each year, the majority of institutions in our dataset that considered race between 1990 and 2016 (up to 56\%) marked that they "considered" race; only up to $14 \%$ marked considering race as "important" in the early 1990 s. Very few 
institutions in any year marked "very important" (no more than $2 \%$ ). In the broader context of challenges to affirmative action, the decision to consider race at all is the most meaningful.

We use a self-reported measure of policy use. Self-reports serve as way for the institution to signal a strategic and political presentation to its peers and thus are not equivalent to a traditional survey measure (Hirschman and Berrey 2017). With a traditional survey, answers might be strategic due to concerns of social desirability (i.e., wanting the interviewer to think well of the respondent), but such answers are usually not publicly identified with the respondent. Because schools know that their answers to the ASC will be displayed in higher education publications like the College Board's BigFuture website, responses to the ASC questions are best understood as institutions' self-presentations to the public and the field. Our models test whether this stated policy is associated with changes in the demographics of entering cohorts.

\section{Sample}

Our sample is composed of Barron's ranked, four-year, public and private not-for-profit, degree-granting colleges and universities. Although more than 3,000 institutions are surveyed by the ASC, just 1,233 are not-for-profit, four-year institutions with selective admissions (i.e., ranked Less Competitive or higher by Barron's). Most of the remaining institutions have open enrollment admissions (i.e., "lower-status" institutions); we remove them from consideration. We include the 152 private, selective institutions in states with affirmative action bans, but not selective public institutions in those states because we examine institutions that can lawfully consider race in admissions and thus can choose their policy. Our dataset contains 1,127 institutions for which we have 27 years of enrollment data (See Tables 2 and 3 for descriptive statistics of covariates).

We use Barron's to classify the competitiveness of those 1,127 institutions' admissions. Barron's rankings are calculated based on an institution's admitted class's weighted average score 
on four criteria: high school class rank, high school grades, standardized test scores, and an institution's selectivity rate (i.e. the ratio of applicants to admitted students). We match the Barron's rankings from 2004 with all institutions in our sample. We chose 2004 because it is a midway point in time and because Barron's rankings change minimally between 2004 and later years. Barron's rankings use these criteria to create six hierarchical groups: "Most Competitive," "Highly Competitive," "Very Competitive," “Competitive," "Less Competitive," and "Noncompetitive." We remove "Noncompetitive" institutions, which have nearly open enrollment policies, and music schools, military academies, and other institutions in the unranked "Special" category, as they use very different enrollment criteria. We collapsed Most Competitive and Highly Competitive together into a category of "Maximally Competitive" because few institutions in the small Most Competitive category changed their consideration of race between 1990 and 2016. This new tier includes those institutions where the highest profile affirmative action political battles took place. Thus, the four categories used in our analyses are "Maximally Competitive," "Very Competitive," "Competitive," and "Less Competitive" and our findings speak to associations across this national status order and not necessarily to processes occurring across other status orders.

\section{Measures}

We collected institutional enrollment and financial data from the IPEDS. Because the National Center for Education Statistics (NCES) changed definitions in our study's range in 2008, we standardize the self-reported racialized definitions in the Fall Enrollment Survey to obtain the IPEDS-defined, mutually exclusive categories of Black, White, Indigenous, Asian and Pacific Islander (API), Latinx, and Non-U.S. resident. ${ }^{1}$ Importantly, because NCES collects these as mutually exclusive categories, Non-U.S. resident includes students from nations outside the United 
States. Though we refer to our findings as enrollment trends by racialized background, Non-U.S. resident is not a racialized background but, rather, an aggregate of people of various nationalities and backgrounds who experience their own distinctive racializations in the U.S. context. This ambiguity in meaning hides how historic U.S. racial segregation changes across higher education because we cannot identify how institutions may be increasing student demographic diversity by shifting towards international enrollments. From these categories, we create six dependent variables: the percentage of each racialized category's composition of first-year, first time undergraduate enrollments at the institution-level each year. Our findings speak to the relationship between first-year enrollments and the policy, and not to the policy's relationship with an institution's total undergraduate enrollments (Long and Bateman 2020).

Our analysis accounts for institutional revenue sources and state-level demographic factors that can influence enrollments at public and private institutions. As governments have slashed public higher education funding, both public and private institutions have increased their enrollments of non-U.S. resident students and, at public institutions, out-of-state students, who pay higher tuition rates. At public institutions, this move is associated with decreased enrollments of Black, Latinx, and lower income in-state students (Jaquette and Curs 2015). Despite the public attention they receive for their tuition costs, private institutions serve similar levels of lowerincome students as public colleges; many private institutions also draw largely from their state populations (Chingos 2017). Given the documented link between increasing out-of-state-resident enrollments and institutional tuition levels, we include measures of financial aid to account for how enrollment trends may be linked to an institution's tuition dependency. Our model includes the percentage of each institution's revenue composed of tuition, as a measure of dependency, as well as the annual state racialized demographics for people who are 15-34 years old (i.e., the 
majority age group of first-year, first-time undergraduate matriculants at selective institutions) (Bound et al. 2019). The state racialized demographic data are from the U.S. Census Bureau. Similar to IPEDS, the racialized designations are mutually-exclusively defined as Black, White, Indigenous, API, and Latinx. We log the state demographic percentage variables in our model because their distributions are skewed across institutions and states and changes in in-state populations can influence enrollment trends.

\section{Analytic Strategy}

When integrating the ASC institutional policy data with the IPEDS enrollment data, we match an institution's fall enrollment numbers with that institution's stated admissions policy for the prior year. For example, the fall 2016 enrollment counts are those students admitted under the 2015 admission policies. This design ensures there is correspondence between when the policy was applied and the class that ultimately enrolled under that policy. Although our enrollment time period between 1990 and 2016 speaks to the admissions policies of 1989-2015, we refer to this simply as enrollment trends between 1990 and 2016. We ensure that our time-variant variables represent the 1989-2015 period. We omit 1989's state-level racialized demographic data because the categories were "White", "Black", and "Other". 2

To evaluate the relationship between a stated policy of considering race in admissions and enrollment demographics between 1990 and 2016, we use a fixed effects linear regression model with robust standard errors clustered at the institution level and with year effects. We model six separate outcome variables using the following:

$$
Y_{i t}=\beta_{1} * R C_{i t}+\beta_{2} \text { Barrons }_{i} * R C_{i t}+\gamma X_{s t}+\delta_{t}+\delta_{i}+\varepsilon_{i t}
$$

Where, $Y_{i t}$ is the percentage of the first-year, first-time undergraduate class that identifies in each of the six demographic backgrounds at institution $i$ in $t$ time. $R C_{i t}$ is a measure of whether the 
institution publicly declared that they considered race as a factor in admissions (Considered Race) with $\beta_{1}$ as the associated regression coefficient, Barrons is the measure of the institution's Barron's ranking with $\beta_{2}$ as the associated regression coefficient for the interaction term, $X_{s t}$ is the matrix of time-varying covariates with $\gamma$ as the associated regression coefficient, $\delta_{t}$ represents year fixed effects to capture changes that are common to all institutions in year t, $\delta_{i}$ represents an institutional fixed effect, and $\varepsilon_{i t}$ represents an institution- and time-variant error term.

Using year fixed effects attends to the influence of trends occurring across institutions in each year that are not attributed to the explanatory variables in our model, thus capturing the influence of aggregate trends. In other words, the year fixed effects minimize the influence of any general reductions or expansions in enrollments across the field, relative to year 1990. We include all institutions' observations $(\mathrm{N}=1,127)$ rather than solely focus on those institutions that had variation in $R C_{i t}$. Observations without variation on $R C_{i t}$ will not contribute to the estimation of $\beta_{1}$, but do contribute to estimates of the other covariates. Our model asks: compared to a school's overall average first-year enrollment rates by racialized background between 1990 and 2016, how much does Black, White, Indigenous, API, Latinx, or Non-U.S. resident student enrollment change in years when the school considered race compared to years when it did not? Given our modeling, we do not include time-invariant covariates, such as Barron's rankings (apart from the interaction term) or institutional sector (public or private). ${ }^{3}$

\section{Limitations}

Though fixed effects modeling is appropriate for our research questions, this approach has limitations. Fixed effects models do not overcome unobserved heterogeneity due to unmeasured characteristics and characteristics that vary over time, they presume time-invariant characteristics have the same effect at each point in time, and they are susceptible to attenuation bias from 
measurement error (Hill et al. 2019). Given their dependence on variation to provide estimates, fixed effects models also typically have low statistical power. This makes it difficult to determine whether null estimates are Type II error (i.e., failing to reject a null hypothesis that should be rejected). For this reason, and because we believe it reflects correct statistical practice, we discuss the substantive importance of estimated coefficients whether or not they are statistically significant according to traditional thresholds (McShane et al. 2019).

Given these limitations, we caution against causal interpretations of our findings. While we find that some enrollment demographic trends are associated with racialized considerations in admission, we cannot conclude that considering race in admissions determines student enrollment by racialized background. The models' inability to capture unmeasured and unobserved heterogeneity in admissions offices is a noteworthy limitation. Administrators' admissions decision-making practices are difficult to measure, and few researchers have been able to access and document admissions offices' practices (Bastedo et al. 2018; Posselt 2016). Enrollment management practices and policies can determine the size of an incoming class and technicalities of offers but are not typically measured or documented longitudinally. In addition, admissions offices' acceptances or rejections are not the only determinants of enrollments. Other practices including outreach, recruitment, and merit aid may affect both the applicant pool and the yield. ${ }^{4}$ Furthermore, organizations' motivations for considering race and interpretations of the policy are neither static nor systematically documented.

\section{RESULTS}

Our analyses demonstrate that the relationship between considering race in admissions and enrollment trends for students of different racialized backgrounds is heterogeneous and varies 
according to an institution's selectivity. Tables 2 and 3 display the descriptive statistics for our model's time-variant and time-invariant measures, and Table 4 shows the regression output.

\section{The Prevalence of Affirmative Action Policies and Institutional Enrollment Trends}

Between 1990 and 2016, 69\% of selective colleges and universities that could legally consider race in admissions did so at some point; one-third of these institutions (31\%) never considered race in admissions (Table 2). By 2016, however, only $30 \%$ of the selective schools across the country that were legally permitted to consider race actually claimed to do so. ${ }^{5}$

Given how enrollment trends by racialized background are highly stratified by status, we began by descriptively assessing the relationship between considering race and institutional status. For each institution, we calculated its average Black student enrollments in years when the institution stated policy usage and when it did not, then took the difference of these sample averages. Figure 1 plots the distribution of these differences across competitiveness tier in a boxand-whiskers plot. For Maximally Competitive institutions, those at the $50^{\text {th }}$ and $75^{\text {th }}$ percentile enrolled cohorts with 0.1 and 0.8 percentage points more Black students; for Less Competitive institutions, these thresholds were $-1.7 \%$ and 0.3 , respectively. Descriptively accounting for variation, we observed that a policy of considering race in admissions was associated with higher average levels of Black student enrollments primarily at higher-status institutions, with more heterogenous associations across the field.

\section{Heterogeneity in the Associations Between Considering Race and Enrollments}

Our main model (Table 4) displays the coefficients for Considered Race and its interaction with competitiveness tier for the 560 institutions that stated using an affirmative action admissions policy. The $\beta_{1}$ estimates represent the average percentage point-change in enrollments of firstyear, first-time undergraduates when these institutions considered race as compared to years when 
they did not. When Maximally Competitive institutions (the base category) stated policy usage, Black student enrollment in the entering class was higher than when those institutions did not consider race (on average 0.77 percentage points higher). The pattern was similar for API and Latinx student enrollments at these Maximally Competitive institutions (0.50 and 0.34 , respectively; estimates were not statistically significant). In contrast, when these same institutions stated policy usage, compared to when they did not, White, Indigenous, and Non-U.S. resident student enrollments were observably lower $(0.41,0.07$, and 0.34 percentage points, respectively; estimates were not statistically significant).

In Figure 2, with our policy variable unchanged, we alternate the base category of status tier in our interaction term for each competitiveness tier to produce new estimates of our interaction term. With the horizontal axis centered at zero, estimates to the right of the line correspond to higher levels of estimated enrollment when institutions stated policy usage, while estimates to the left of the line correspond to lower levels when institutions stated no usage. Though Figure 2 and Table 4 are based on the same analysis, Figure 2's estimates at each tier enable interpreting an estimate at each tier relative to itself as the base category.

Figure 2 shows discernable patterns primarily in Black and Non-U.S. resident student enrollments and more mixed patterns in student enrollments for other demographic backgrounds, with many estimates near zero. When Maximally Competitive and Very Competitive institutions stated policy usage, their entering cohorts were, respectively and on average, 0.77 and 0.35 percentage points higher in their proportion of Black student enrollments compared to years when they did not have the policy. This trend is consistent with research showing that the most prestigious public universities experience the largest decline in Black student enrollments when affirmative action bans go into effect (Long and Bateman 2020). We found a similar association 
of higher API and Latinx student enrollments at Maximally Competitive institutions (0.50 and 0.34, respectively). However, the association was reversed at Very Competitive institutions for API student enrollments (0.23 percentage points lower). Latinx student enrollments at Very Competitive institutions were estimated at approximately 0 (0.02).

In contrast, when Competitive and Less Competitive institutions stated policy usage, Black student enrollments were 0.60 and 1.98 percentage points lower. This trend held for Latinx student enrollments as well (0.13 and 0.25, respectively). When Less Competitive institutions stated policy usage, average API student enrollments were higher (0.26 percentage points); enrollments were estimated at zero at Competitive institutions. In sum, while Latinx student enrollments followed a similar pattern as those of Black student enrollments, these estimates' magnitudes were smaller and not statistically significant. The estimate of Black student enrollments at Very Competitive institutions and all API estimates were not statistically significant.

The pattern for White and Non-U.S. resident student enrollments across competitive tiers was generally the reverse of the trends in Black student enrollments. As noted above and shown in Table 4, when Maximally Competitive institutions stated policy usage, White and Non-U.S. resident student enrollments were, on average, 0.41 and 0.34 percentage points lower than when institutions stated no policy usage. A similar relationship was also observed at Very Competitive institutions for White student enrollments $(0.30)$ but was essentially zero for Non-U.S. resident students (-0.03). In contrast, when Competitive institutions stated policy usage, average Non-U.S. residents student enrollments were 0.40 percentage points higher, and changes in White student enrollments were negligible (-0.07). When Less Competitive institutions stated policy usage, both White and Non-U.S. resident student enrollments were, on average, 1.52 and 0.52 percentage 
points higher. Among these estimates, only the relationships for Non-U.S. residents observed at Less Competitive and Competitive institutions were statistically significant.

For Indigenous student enrollments, the estimates' magnitudes were small. When Maximally Competitive, Competitive, and Less Competitive institutions stated policy usage, Indigenous student enrollments were close to zero $(-0.07,-0.07$, and -0.02 percentage points, respectively); at Very Competitive institutions, the association was reversed ( 0.08 percentage points). None of these estimates were statistically significant.

Covariates. To interpret log-transformed estimates, we multiply the coefficient of the variable in Table 4 by the natural log of the change we are trying to estimate. For example, as it pertains to the relationship between changes in a state's White population from ages 15-34 and White student enrollment trends, on average, a $1 \%$ increase in a state's White population is associated with a $0.11(0.11=11.17 * \ln (1.01))$ percentage point increase in enrollments, and a 0.06 , 0, 0.03, and 0.08 percentage point decline in Black, Indigenous, API and Latinx student enrollments, respectively. Similarly, a 1\% increase in a state's API population, on average, is associated with a 0.03 percentage point decline in Latinx student enrollments. The remaining estimates associated with state racialized demographics are all below a 0.02 percentage point change in enrollments.

Though these estimates' magnitudes are small, the associations suggest that increases in a state's White population are associated with decreased enrollments of students from non-White backgrounds; no other estimate showed same-racialized background enrollment increases alongside decreases in all other-racialized background enrollments. This could reflect state contexts in which there is fear of racial backlash for diversifying prestigious state institutions, as was the case for why states adopted affirmative action bans between 1995 and 2012 (Baker 2019). 
Finally, our estimates for the relationship between enrollment and tuition revenue were, on average, zero. It is plausible that, while institutions may enroll more high-tuition paying students to grapple with decreased public investment (Jaquette and Curs 2015), relative to other sources of revenue, tuition may not be the primary budgetary solution tied to undergraduate enrollment trends by racialized and residency background, as changes in graduate tuition inform enrollment management decisions.

\section{DISCUSSION}

\section{Implications for Black Student Enrollment}

Our study unsettles the presumed relationship between a policy of considering race in admissions and greater Black student enrollment. Figure 2 shows that Maximally Competitive institutions enrolled cohorts with higher levels of Black students when they stated affirmative action policy usage (approximately 0.8 percentage points) compared to when they did not. Among Competitive and Less Competitive institutions, we found they enrolled cohorts with higher proportions of Non-U.S. resident students when they stated policy usage (approximately 0.4 and 0.5 percentage points, respectively) and lower proportions of Black students (approximately 0.6 and 2 percentage points, respectively).

While an approximately 0.8 percentage point boost in Black enrollment at Maximally Competitive institutions may sound small, these numbers are substantively significant. They also are plausible when compared with the estimated effects of state bans (Long and Bateman 2020). Because Black students make up a small proportion of first-year students at higher-status institutions, modest changes in Black students' enrollment constitute a sizeable proportion of those institutions' current enrollment levels. From the 2016 statistics in Table 1, a 0.8 percentage point higher level of enrollments could represent an average 14-15\% increase in Black student 
enrollment at Maximally Competitive institutions (i.e., a change of 0.8 percentage points makes up $14 \%$ of $5.9 \%$ and $15 \%$ of $5.5 \%$ ). Yet simply because affirmative action admissions policy corresponds to a consequential increase in Black enrollments at the higher-status institutions does not mean that the same relationship holds for middle-status ones. Particularly for the least competitive middle-status institutions (i.e., Less Competitive), stated policy usage is associated with an 7-9\% reduction in Black student enrollments and an 18-19\% increase in Non-U.S. Resident enrollments.

\section{Middle-Status Institutions and Organizational Policy in a Racialized Status Order}

These empirical findings bring to the forefront the importance of accounting for how racialized policy intended to produce more egalitarian racialized outcomes can operate for middleand lower-status organizations. Since the 1990s, middle-status colleges and universities have increasingly abandoned their affirmative action admissions policies while simultaneously enrolling more racially-heterogenous cohorts (Hirschman and Berrey 2017). As our findings show, middle-status institutions (those categorized as Very Competitive, Competitive, and Less Competitive) that continue to have a stated admissions policy of considering race are not necessarily enrolling more Black students. This belies how affirmative action is popularly

understood, an understanding rooted in the experience of higher-status institutions where it is associated with higher Black enrollments. For middle-status institutions, this statistical association does not hold.

From our findings, we can characterize the U.S. higher education's contemporary racialized status order as comprising three tiers: higher-status institutions that $d o$ consider race in admissions but do not enroll racially heterogenous cohorts, middle-status institutions that do not consider race but do enroll racially heterogenous cohorts, and lower-status open-access or non-selective 
institutions that enroll disproportionately high numbers of Black, Indigenous, and Latinx students. We argue that affirmative action as a racialized policy is an element of this field-level racialized status order but, for middle-status organizations, the policy effects may not match the cultural associations tethered to the policy (Berrey 2015; Phillips and Zuckerman 2001; Ray 2019).

For many institutions, having an affirmative action admissions policy on the books seems to continue to signal an institution's legitimacy in the elite-centric status order, despite successful conservative opposition. A vigorous stated commitment to affirmative action can convey a general commitment to racial justice and to Black students specifically. This signaling may help shield institutions, of any competitive status, from continued anti-racist activist pressure. For elite public institutions like the University of Michigan, where the policy is now impermissible, the assumption that affirmative action is necessary to enroll a racially diverse student body also can help to justify low enrollment levels of Black, Latinx, and Indigenous students.

Yet, contrary to assumptions, having an affirmative action policy may not yield substantive increases in Black student enrollments at middle-status institutions. Because our study cannot provide direct evidence of admissions office practices, we cannot definitively answer why this might happen. We do not have evidence on how middle-status institutions use the policy, if at all. It could be that they keep the policy for legitimacy purposes yet disregard it in practice because it is too costly to implement or because they do not perceive it as necessary. Notably, middle-status institutions already have substantially more racially heterogenous student bodies and enroll a growing proportion of Black and Latinx applicants compared to their higher status peers, given racialized inequality in K-12 education and recent declines in racialized high school graduation gaps (Baker, Klasik, and Reardon 2018). The leadership of middle-status institutions may not be motivated to proactively boost the proportion of Black, Latinx, or Indigenous students, if they 
perceive that this would make their institutions appear less prestigious. Research shows that on their undergraduate admissions websites, less selective institutions, unlike their elite peers, tend to not mention their student bodies' racialized demographics (Holland and Ford 2020). Yet, these explanations (i.e., cost, perceived as unnecessary) would not account for the lower Black student enrollment associated with the policy.

We consider this finding a puzzle requiring further research to untangle. We can only tentatively speculate why middle-status institutions tend to enroll fewer Black students, more White students, and slightly more non-US students when they claim to consider race in admissions. Conceivably, for middle-status institutions, policy usage may have minimal effects on enrollments. In that case, they might experience these observed enrollment trends if they dropped their policy of considering race because they anticipated Black student enrollments would increase due to either other policy changes (e.g., new financial aid programs) or demographic shifts in their applicant pool not captured in our measures (as the College of Charleston asserted). This would induce a negative association between stated policy usage and Black student enrollments. Simultaneously, administrators may have pursued non-U.S. resident students who pay higher tuition and/or non-Black student enrollments who contribute to their demographic diversity. However, we cannot directly test these speculations (review footnote 4).

In sum, middle-status institutions may have an explicit affirmative action admission policy because it is a normatively legitimate practice in the field, but that policy may not be implemented in the organization, or at least not implemented for increasing Black student enrollment. We interpret this pattern as consistent with an explanation centering middle class status conformity and tethering: middle-status institutions may maintain racialized policy that signals conformity to racialized elite norms, yet may not use it to achieve the racialized outcome emphasized in elite and 
popular understandings of policy. We offer this interpretation cautiously, given our data limitations.

\section{CONCLUSION}

While affirmative action's meanings and objectives have been politically contentious, actors on all sides assume that institutions enroll more Black students when they consider race in admissions. In contrast, we document significant heterogeneity in the relationship between considering race and enrollment trends across the field's status hierarchy. This heterogeneity calls for an evaluation of what considering race in admissions involves and how racialized policy intended to counter racial inequality is used and understood for institutions across the status system.

This study advances racialized organizations theory by examining an explicitly racialized policy at the field level. It contributes to an understanding of racialized organizational policies that are intended to produce more egalitarian racialized outcomes and the role of such policies in racialized status orders. Our findings highlight the importance of disentangling the dynamics of adoption, implementation, and abandonment of racialized organizational policies from the elitebased, progressive cultural associations tethered to those policies. This perspective may be valuable for investigating the dynamics of other racialized policies in higher education or other fields similarly characterized by hierarchical status orders. For example, institutions have increasingly created "Chief Diversity Officer" positions (Wilson 2013). We would hypothesize that the meanings tethered to this position would be determined by its associations at elite institutions, but may be disconnected from its practical significance at middle-status institutions.

Future research on the consideration of race in admissions could build on our findings to better understand what prompts institutions to have an affirmative action admissions policy, how 
institutions implement the policy, and the consequences of doing so across status orders (Baker 2019). Identifying institutional rationales may reveal coalitional linkages across the higher education field and the degree to which considering race in admissions is a constitutive element of the status order. In addition, how racialized policies are understood and how they matter for student enrollments in the status order's lower-status tier, at for-profit institutions, merits attention, especially since the status order depends on these institutions' continuation. Such notoriously exploitative institutions help to institutionalize racialized inequality in higher education via their recruitment and enrollment of historically minoritized students (McMillan Cottom 2017). In this tier of the racialized status order, considering race in admissions may represent predatory inclusion more than racialized equity (Seamster and Charron-Chénier 2017).

Finally, although the average increases in Black student enrollments associated with stated consideration of race in admissions are modest at the most elite institutions, our results do not imply that institutions should abandon these practices. For instance, affirmative action significantly increased lower-income Black and Latinx applicants' access to the most elite institutions in California until 1998. The elimination of affirmative action, in turn, led to substantial educational and labor market losses for applicants from these same racially and economically minoritized backgrounds over the next twenty years (Bleemer 2020). One promising policy path to both racialized and economic inclusion is to embed the consideration of race within class-based affirmative action (Reardon et al. 2018), and expand the conversation on equity to focus on inequality between institutions. Small changes in enrollments at higher-status institutions provide benefits for student from historically marginalized backgrounds, though increasing access to these institutions will not fundamentally alter the racialized status order. Affirmative action in higher 
education must mean fighting for resources at middle- and lower-status institutions at the same time as we fight to desegregate and integrate higher-status institutions. 
Notes

${ }^{1}$ Racialized categories homogenize and rank intra-community diversity through essentialist notions of race, for the purpose of White supremacy in the U.S. settler state context (McKay 2019). The category of Indigenous is a creation of the settler colonial state that obfuscates the prevailing self-definition among Indigenous communities as distinct sovereign nations. We do not wish to obscure Indigenous nations' sovereignty claims by marking them a "race".

${ }^{2}$ We excluded the state-level demographics in our analyses to assess whether this altered our results. Our results (available upon request) were substantively similar.

${ }^{3}$ We assessed our findings specifically for public and private institutions (available upon request). These results were not directly comparable to this study's analyses across competitiveness tiers because there were too few institutions in some cells to analyze the public/private distinction at the same time as competitiveness as operationalized here. Given this limitation, future research should explore how racialized policies are enacted within these organizational cultures.

${ }^{4}$ We included financial aid variables within our observed period in separate analyses (available upon request). Using IPEDS data available after 1999, we included measures of average expenditure levels on instruction and average institutional, federal, and state/local grant amounts; average student loan amounts; and in-district, in-state, and out-of-state average tuition levels. This modeling did not alter the estimated relationship. Though we do not extrapolate this conclusion to our study's period, our main model estimates' magnitudes are sensitive to the specification of time periods and graduate student tuition levels. Future research should explore how time periods, graduate tuition levels, and international residency alter the estimated relationships.

${ }^{5}$ About half (50.7\%) of these institutions switched between considering and not considering race, though switching more than once was comparatively rare. 
References

Anderson, James D. 1988. The Education of Blacks in the South, 1860-1935. Chapel Hill, NC: University of North Carolina Press.

Baker, Dominique J. 2019. "Pathways to Racial Equity in Higher Education: Modeling the Antecedents of State Affirmative Action Bans." American Educational Research Journal.

Baker, Rachel, Daniel Klasik, and Sean F. Reardon. 2018. "Race and Stratification in College Enrollment Over Time, Race and Stratification in College Enrollment Over Time." AERA Open 4(1).

Bastedo, Michael N., Nicholas A. Bowman, Kristen M. Glasener, and Jandi L. Kelly. 2018. "What Are We Talking About When We Talk About Holistic Review? Selective College Admissions and Its Effects on Low-SES Students." The Journal of Higher Education 89(5):782-805.

Berrey, Ellen. 2015. The Enigma of Diversity: The Language of Race and the Limits of Racial Justice. Chicago, IL: University of Chicago Press.

Bleemer, Zachary. 2020. Proposition 209 and Affirmative Action at the University of California. UC-CHP Policy Brief 2020.4. Center for Studies in Higher Education.

Bound, John, Breno Braga, Gaurav Khanna, and Sarah Turner. 2019. Public Universities: The Supply Side of Building a Skilled Workforce. Working Paper. 25945. National Bureau of Economic Research.

Bowers, Paul. 2018a. "Affirmative Action Comes to a Quiet End at College of Charleston." The Post and Courier, July 29.

Bowers, Paul. 2018b. "College of Charleston Resumes Affirmative Action after 2-Year Hiatus." The Post and Courier, July 31.

Brown-Nagin, Tomiko. 2005. "The Transformative Racial Politics of Justice Thomas? The Grutter v. Bollinger Opinion.” Journal of Constitutional Law 7(3):787-807.

Carter, Courtney Myrtle. 2015. The Institutionalization of Diversity at an HBCU and Its Implications for Racialized School Mission. University of Illinois at Chicago.

Chingos, Matthew M. 2017. Don't Forget Private, Non-Profit Colleges. Vol 2, 9. Washington DC: The Brookings Institution.

Desilver, Drew. 2019. “A Majority of U.S. Colleges Admit Most Students Who Apply.” Pew Research Center.

Fields, Karen E., and Barbara J. Fields. 2012. Racecraft: The Soul of Inequality in American Life. Brooklyn, NY: Verso Books. 
Grodsky, Eric, and Demetra Kalogrides. 2008. "The Declining Significance of Race in College Admissions Decisions." American Journal of Education 115(1):1-33.

Harris, Cheryl I. 1993. "Whiteness as Property.” Harvard Law Review 106(8):1707-91.

Hill, Terrence D., Andrew P. Davis, J. Micah Roos, and Michael T. French. 2019. "Limitations of Fixed-Effects Models for Panel Data.” Sociological Perspectives 1-13.

Hirschman, Daniel, and Ellen Berrey. 2017. "The Partial Deinstitutionalization of Affirmative Action in U.S. Higher Education, 1988 to 2014.” Sociological Science 4:449-68.

Holland, Megan M., and Karly Sarita Ford. 2020. "Legitimating Prestige through Diversity: How Higher Education Institutions Represent Ethno-Racial Diversity across Levels of Selectivity." The Journal of Higher Education 0(0):1-30.

Jaquette, Ozan, and Bradley R. Curs. 2015. "Creating the Out-of-State University: Do Public Universities Increase Nonresident Freshmen Enrollment in Response to Declining State Appropriations?" Research in Higher Education 56:535-65.

Johnson, Matthew. 2020. Undermining Racial Justice: How One University Embraced Inclusion and Inequality. Cornell University Press.

Karabel, Jerome. 2005. The Chosen: The Hidden History of Admission and Exclusion at Harvard, Yale, and Princeton. Boston, MA: Houghton Mifflin Company.

Lempert, Richard O. 2016. "Mismatch and Science Desistance: Failed Arguments against Affirmative Action." UCLA Law Review Discourse 64(136-173).

Lipson, Daniel N. 2007. "Embracing Diversity: The Institutionalization of Affirmative Action as Diversity Management at UC-Berkeley, UT-Austin, and UW-Madison.” Law \& Social Inquiry 32(4):985-1026.

Long, Mark C., and Nicole A. Bateman. 2020. "Long-Run Changes in Underrepresentation After Affirmative Action Bans in Public Universities." Educational Evaluation and Policy Analysis.

McKay, Dwanna L. 2019. "Real Indians: Policing or Protecting Authentic Indigenous Identity?" Sociology of Race and Ethnicity 1-14.

McMillan Cottom, Tressie. 2017. Lower Ed: The Troubling Rise of For-Profit Colleges in the New Economy. New York, NY: The New Press.

McShane, Blakeley B., David Gal, Andrew Gelman, Christian Robert, and Jennifer L. Tackett. 2019. “Abandon Statistical Significance.” The American Statistician 73(sup1):235-45.

Okechukwu, Amaka. 2019. To Fulfill These Rights: Political Struggle Over Affirmative Action and Open Admissions. New York: Columbia University Press. 
Phillips, Damon J., and Ezra W. Zuckerman. 2001. "Middle-Status Conformity: Theoretical Restatement and Empirical Demonstration in Two Markets." American Journal of Sociology 107(2):379-429.

Posselt, Julie R. 2016. Inside Graduate Admissions: Merit, Diversity, and Faculty Gatekeeping. Cambridge, MA: Harvard University Press.

Posselt, Julie R., Ozan Jaquette, Rob Bielby, and Michael N. Bastedo. 2012. "Access Without Equity: Longitudinal Analyses of Institutional Stratification by Race and Ethnicity, 1972-2004." American Educational Research Journal 49(6):1074-1111.

Ray, Victor. 2019. "A Theory of Racialized Organizations.” American Sociological Review 84(1):26-53.

Reardon, Sean F., Rachel Baker, Daniel Kasman, and Joseph Townsend. 2018. "Can Socioeconomic Status Substitute for Race in Affirmative Action College Admissions Policies? Evidence from a Simulation Model." Journal of Policy Analysis and Management 37(3):630-57.

Sander, Richard, and Stuart Taylor. 2012. Mismatch: How Affirmative Action Hurts Students It's Intended to Help, and Why Universities Won't Admit It. New York, NY: Basic Books.

Scott, W. Richard. 2014. Institutions and Organizations: Ideas, Interests, and Identities. Fourth edition. SAGE Publications, Inc.

Seamster, Louise, and Raphaël Charron-Chénier. 2017. "Predatory Inclusion and Education Debt: Rethinking the Racial Wealth Gap." Social Currents 4(3):199-207.

Shaw, Matthew P. 2016. "Bans on Affirmative Action in States with a History of StateSponsored Discrimination." in School Integration Matters: Research-Based Strategies to Advance Equity, edited by E. Frankenberg, L. M. Garces, and M. Hopkins. Teachers College Press.

Stevens, Chang, Mitchell J., and Josipa Roksa. 2011. "The Diversity Imperative in Elite Admissions." Pp. 63-73 in Diversity in American Higher Education, edited by L. M. Stulberg and S. L. Weinberg. New York, NY: Routledge.

Teddlie, Charles, and John A. Freeman. 2002. "Twentieth-Century Desegregation in U.S. Higher Education: A Review of Five Distinct Historical Era." Pp. 77-102 in Racial Crisis in American Higher Education: Continuing Challenges for the Twenty-first Century, Revised Edition, edited by W. A. Smith, P. G. Altbach, and K. Lomotey. Albany, NY: State University of New York Press.

Thelin, John R. 2004. A History of American Higher Education. Baltimore: Johns Hopkins University Press.

Wilder, Craig Steven. 2013. Ebony and Ivy: Race, Slavery, and the Troubled History of America's Universities. New York, NY: Bloomsbury Publishing. 
Wilson, Jeffery L. 2013. "Emerging Trend: The Chief Diversity Officer Phenomenon within Higher Education." The Journal of Negro Education 82(4):433-45.

Wooten, Melissa E. 2006. "Race and Strategic Organization.” Strategic Organization 4(2):19199. 
Table 1. Average Percentage of Enrollments at Institutions that Stated Policy Usage and Those That Did Not, by Barron's Selectivity Tier in 2016

\begin{tabular}{lcccccccc} 
& $\begin{array}{c}\text { Maximally } \\
\text { Competitive }\end{array}$ & \multicolumn{2}{c}{$\begin{array}{c}\text { Very } \\
\text { Competitive }\end{array}$} & Competitive & \multicolumn{2}{c}{$\begin{array}{c}\text { Less } \\
\text { Competitive }\end{array}$} \\
\hline & \multicolumn{1}{c}{ Yes } & No & Yes & No & Yes & No & Yes & No \\
\hline Considers race? & & & & & & & & \\
\hline $\begin{array}{l}\text { Percentage of institution's } \\
\text { first-year enrollments }\end{array}$ & 5.9 & 5.5 & 5.1 & 7.8 & 7.1 & 15.7 & 27.9 & 22.2 \\
$\quad$ Black students & 59.0 & 71.9 & 68.3 & 65.3 & 73.4 & 63.1 & 54.9 & 55.8 \\
$\quad$ White students & 0.2 & 0.3 & 0.2 & 0.4 & 0.3 & 0.5 & 0.4 & 0.8 \\
$\quad \begin{array}{l}\text { Indigenous students } \\
\text { Asian and Pacific }\end{array}$ & 12.1 & 5.5 & 8.5 & 9.0 & 4.8 & 3.7 & 3.1 & 3.6 \\
$\begin{array}{l}\text { Islander students } \\
\text { Latinx students }\end{array}$ & 9.9 & 9.3 & 8.8 & 10.9 & 9.4 & 10.7 & 7.9 & 11.1 \\
$\quad \begin{array}{l}\text { Non-U.S. resident } \\
\text { students }\end{array}$ & 9.7 & 5.5 & 6.1 & 4.2 & 2.9 & 2.8 & 2.8 & 2.7 \\
\hline
\end{tabular}

Note: These values are calculated using average enrollment levels within each Barron's tier in each year; thus, the percentages within each column do not sum to $100(\mathrm{~N}=1,127)$. 
Table 2. Sample Descriptive Statistics, 1990-2016.

\begin{tabular}{lcccc}
\hline \multirow{2}{*}{ Institutional Characteristics } & \multicolumn{2}{c}{ Total dataset } & \multicolumn{2}{c}{ Sample } \\
& $\mathrm{N}$ & Percentage & $\mathrm{N}$ & Percentage \\
\hline Total Institutions & 1,233 & 100 & 1,127 & 100 \\
$\quad$ Public & 431 & 35.0 & 331 & 29.4 \\
$\quad$ Private & 802 & 65.0 & 796 & 70.6 \\
Historically Black Colleges \& Universities & 64 & 5.2 & 60 & 5.3 \\
Considered race anytime & 852 & 69.1 & 783 & 69.5 \\
Never considered race anytime & 381 & 30.9 & 344 & 30.5 \\
In states with bans until 2016 & 253 & 20.5 & 152 & 13.5 \\
In states with no bans & 980 & 79.5 & 975 & 86.5 \\
Considered race in 1990 & 650 & 52.7 & 595 & 52.8 \\
Had variation in policy & 625 & 50.7 & 560 & 49.7 \\
Considered race in 2016 & 367 & 29.8 & 363 & 32.2 \\
& & & & \\
Among institutions with variation in policy & 625 & 100 & 560 & 100 \\
Stopped considering once & 494 & 79 & 434 & 77.5 \\
Stopped considering 2+ & 76 & 12.2 & 71 & 12.7 \\
Began considering once & 291 & 46.6 & 277 & 49.5 \\
Began considering 2+ & 45 & 7.2 & 43 & 7.7 \\
Barron's Ranking & & & & \\
Maximally Competitive & & & & \\
Very Competitive & 152 & 12.3 & 144 & 12.8 \\
Competitive & 246 & 20.0 & 228 & 20.2 \\
Less Competitive & 572 & 46.4 & 519 & 46.1 \\
\hline
\end{tabular}

Note: Sample refers to those selective four-year, not-for-profit institutions that could lawfully use affirmative action admissions, had enrollment data, and had a Barron's ranking. 
Table 3. Descriptive Statistics of Time-Variant Variables Used In Analysis, 1990-2016.

\begin{tabular}{lcccc}
\hline & \multicolumn{2}{c}{ Total dataset } & \multicolumn{2}{c}{ Sample } \\
Variation Measures & Mean & SD & Mean & SD \\
\hline & & & & \\
State Demographic Measures & & & & \\
$\quad$ State percentage of Black residents & 13.80 & 9.03 & 14.07 & 9.25 \\
$\quad$ State percentage of White residents & 68.75 & 15.51 & 69.93 & 14.84 \\
State percentage of Indigenous residents & 0.85 & 1.76 & 0.78 & 1.63 \\
State percentage of API residents & 4.34 & 4.63 & 4.18 & 4.60 \\
State percentage of Latinx residents & 12.3 & 11.6 & 11.04 & 10.28 \\
& & & & \\
Institutional Financial Measures & & & & \\
Percentage of institutional revenue derived & 44.01 & 85.91 & 45.80 & 89.52 \\
from tuition & $16,0749.80$ & $59,3614.90$ & $135,500.9$ & $607,084.70$ \\
Instructional hours - UG & $31,334.64$ & $71,624.05$ & $27,460.44$ & $70,249.60$ \\
Instructional hours - Grad & $\$ 3,902.06$ & $1,248.87$ & $3,920.52$ & $1,259.41$ \\
Average federal grants, per student & $\$ 8,715.41$ & $7,011.32$ & $9,183.38$ & $7,119.45$ \\
Average institutional grants, per student & & & & \\
Average local and state grants, per student & $\$ 3,081.16$ & $\$ 1,803.81$ & $3,101.85$ & $1,782.01$ \\
\hline
\end{tabular}

Note: Sample refers to those selective four-year, not-for-profit institutions that could lawfully use affirmative action admissions, had enrollment data, and had a Barron's ranking. 
Table 4. Estimates from Fixed Effects Model, 1990-2016.

\begin{tabular}{|c|c|c|c|c|c|c|}
\hline Variables & $\begin{array}{c}\text { Black } \\
\text { student } \\
\text { proportion } \\
\end{array}$ & $\begin{array}{c}\text { White } \\
\text { student } \\
\text { proportion } \\
\end{array}$ & $\begin{array}{l}\text { Indigenous } \\
\text { student } \\
\text { proportion } \\
\end{array}$ & $\begin{array}{l}\text { API student } \\
\text { proportion }\end{array}$ & $\begin{array}{c}\text { Latinx } \\
\text { student } \\
\text { proportion } \\
\end{array}$ & $\begin{array}{l}\text { Non-U.S. } \\
\text { resident student } \\
\text { proportion }\end{array}$ \\
\hline $\begin{array}{l}\text { Considered } \\
\text { race X } \\
\text { Maximally } \\
\text { Competitive }\end{array}$ & $(0.28)$ & -0.41 & $(0.04)$ & 0.50 & $(0.30)$ & $(0.53)$ \\
\hline $\begin{array}{l}\text { Considered } \\
\text { race X Very } \\
\text { Competitive }\end{array}$ & $\begin{array}{l}-0.42 \\
(0.35)\end{array}$ & $\begin{array}{c}0.11 \\
(0.92)\end{array}$ & $(0.06)$ & $(0.41)$ & $(0.33)$ & $\begin{array}{c}0.31 \\
(0.56)\end{array}$ \\
\hline $\begin{array}{l}\text { Considered } \\
\text { race X } \\
\text { Competitive }\end{array}$ & $\begin{array}{c}-1.36 * * * \\
(0.39)\end{array}$ & $\begin{array}{r}0.34 \\
(0.88)\end{array}$ & $\begin{array}{l}0.13^{*} \\
(0.06)\end{array}$ & $\begin{array}{l}-0.49 \\
(0.38)\end{array}$ & $\begin{array}{l}-0.47 \\
(0.33)\end{array}$ & $\begin{array}{l}0.74 \\
(0.56)\end{array}$ \\
\hline $\begin{array}{l}\text { Considered } \\
\text { race X Less } \\
\text { Competitive }\end{array}$ & $(0.57)$ & $\begin{array}{l}1.94 \\
(1.13)\end{array}$ & $\begin{array}{r}0.05 \\
(0.14)\end{array}$ & $\begin{array}{l}-0.24 \\
(0.39)\end{array}$ & $(0.37)$ & $\begin{array}{l}0.87 \\
(0.57)\end{array}$ \\
\hline $\begin{array}{l}\text { State } \\
\text { percentage } \\
\text { (logged) }\end{array}$ & & & & & & \\
\hline White & $\begin{array}{l}-5.96 \\
(4.48)\end{array}$ & $\begin{array}{l}11.17^{*} \\
(5.39)\end{array}$ & $\begin{array}{l}-0.11 \\
(0.31)\end{array}$ & $\begin{array}{l}-3.20^{*} \\
(1.47)\end{array}$ & $\begin{array}{l}-7.73 * * * \\
(1.95)\end{array}$ & $\begin{array}{c}0.81 \\
(1.60)\end{array}$ \\
\hline Black & $\begin{array}{l}-0.01 \\
(0.61)\end{array}$ & $\begin{array}{c}0.19 \\
(1.03)\end{array}$ & $\begin{array}{l}-0.06 \\
(0.11)\end{array}$ & $\begin{array}{c}0.18 \\
(0.17)\end{array}$ & $\begin{array}{c}0.21 \\
(0.29)\end{array}$ & $\begin{array}{c}0.13 \\
(0.37)\end{array}$ \\
\hline Indigenous & $\begin{array}{c}2.15 \\
(1.51)\end{array}$ & $\begin{array}{c}0.93 \\
(2.37)\end{array}$ & $\begin{array}{c}0.39 \\
(0.27)\end{array}$ & $\begin{array}{c}0.74 \\
(0.74)\end{array}$ & $\begin{array}{l}-2.31 * * \\
(0.71)\end{array}$ & $\begin{array}{c}0.87 \\
(0.72)\end{array}$ \\
\hline API & $\begin{array}{l}1.56 \\
(1.23)\end{array}$ & $\begin{array}{l}-1.34 \\
(2.08)\end{array}$ & $\begin{array}{l}-0.04 \\
(0.16)\end{array}$ & $\begin{array}{c}2.04 \\
(1.17)\end{array}$ & $\begin{array}{l}-3.35 * * * \\
(0.72)\end{array}$ & $\begin{array}{c}0.94 \\
(1.03)\end{array}$ \\
\hline Latinx & $\begin{array}{l}1.85^{* *} \\
(0.59)\end{array}$ & $\begin{array}{l}-0.10 \\
(0.83)\end{array}$ & $\begin{array}{l}-0.00 \\
(0.07)\end{array}$ & $\begin{array}{l}-0.30 \\
(0.25)\end{array}$ & $\begin{array}{l}-0.96 * * * \\
(0.24)\end{array}$ & $\begin{array}{l}-0.24 \\
(0.27)\end{array}$ \\
\hline Revenue & 0.00 & -0.00 & 0.00 & 0.00 & 0.00 & -0.00 \\
\hline Constant & $\begin{array}{c}(0.00) \\
36.01 \\
(19.29)\end{array}$ & $\begin{array}{c}(0.00) \\
29.65 \\
(23.54)\end{array}$ & $\begin{array}{c}(0.00) \\
1.51 \\
(1.41)\end{array}$ & $\begin{array}{l}(0.00) \\
16.81 * * \\
(6.45)\end{array}$ & $\begin{array}{c}(0.00) \\
37.76^{* * *} \\
(8.40)\end{array}$ & $\begin{array}{l}(0.00) \\
-0.62 \\
(7.06)\end{array}$ \\
\hline $\begin{array}{l}\text { Observations } \\
\text { R-squared }\end{array}$ & $\begin{array}{r}28,222 \\
0.06\end{array}$ & $\begin{array}{r}28,222 \\
0.38\end{array}$ & $\begin{array}{r}28,222 \\
0.01\end{array}$ & $\begin{array}{r}28,222 \\
0.04\end{array}$ & $\begin{array}{r}28,222 \\
0.40\end{array}$ & $\begin{array}{l}28,222 \\
0.05\end{array}$ \\
\hline
\end{tabular}


Number of

1,12

127

1,127

1,127

1,127

1,127

1,127

The fixed effects model is with reference to 1990. "Considered race" is dichotomously coded, with the reference category as no institutional policy use in admissions. The Barron's rankings' reference category is Maximally Competitive. The demographic variables are logged. Robust standard errors in parentheses. ${ }^{* * *} \mathrm{p}<0.001,{ }^{*} \mathrm{p}<0.01,{ }^{*} \mathrm{p}<0.05$ 


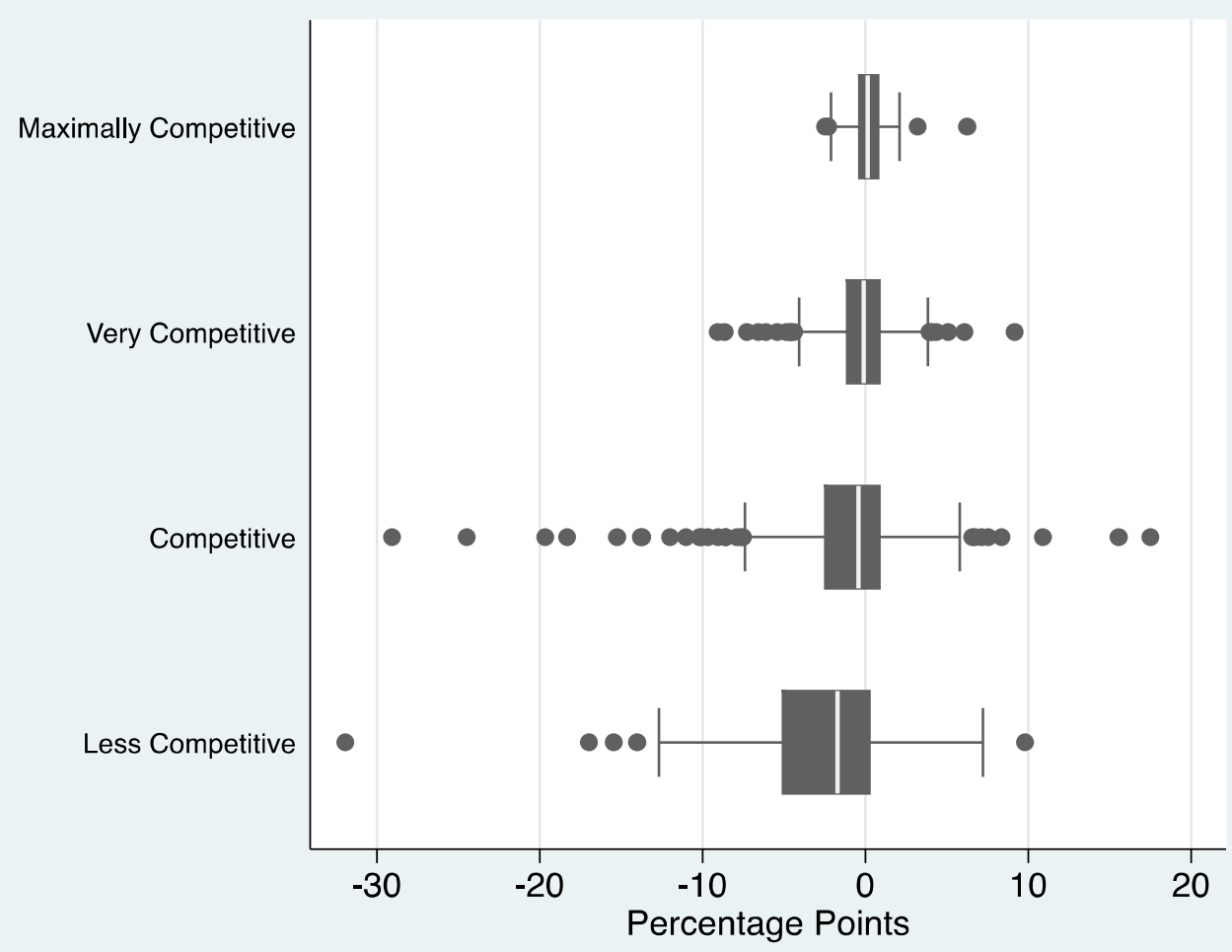

Figure 1. Distribution of the Institutional Differences between Average First-Year Black Student Enrollments in Years When the Institution Stated Policy Usage and When it Did Not, by Barron's Selectivity Tier, 1990-2016 (N=1,127). 


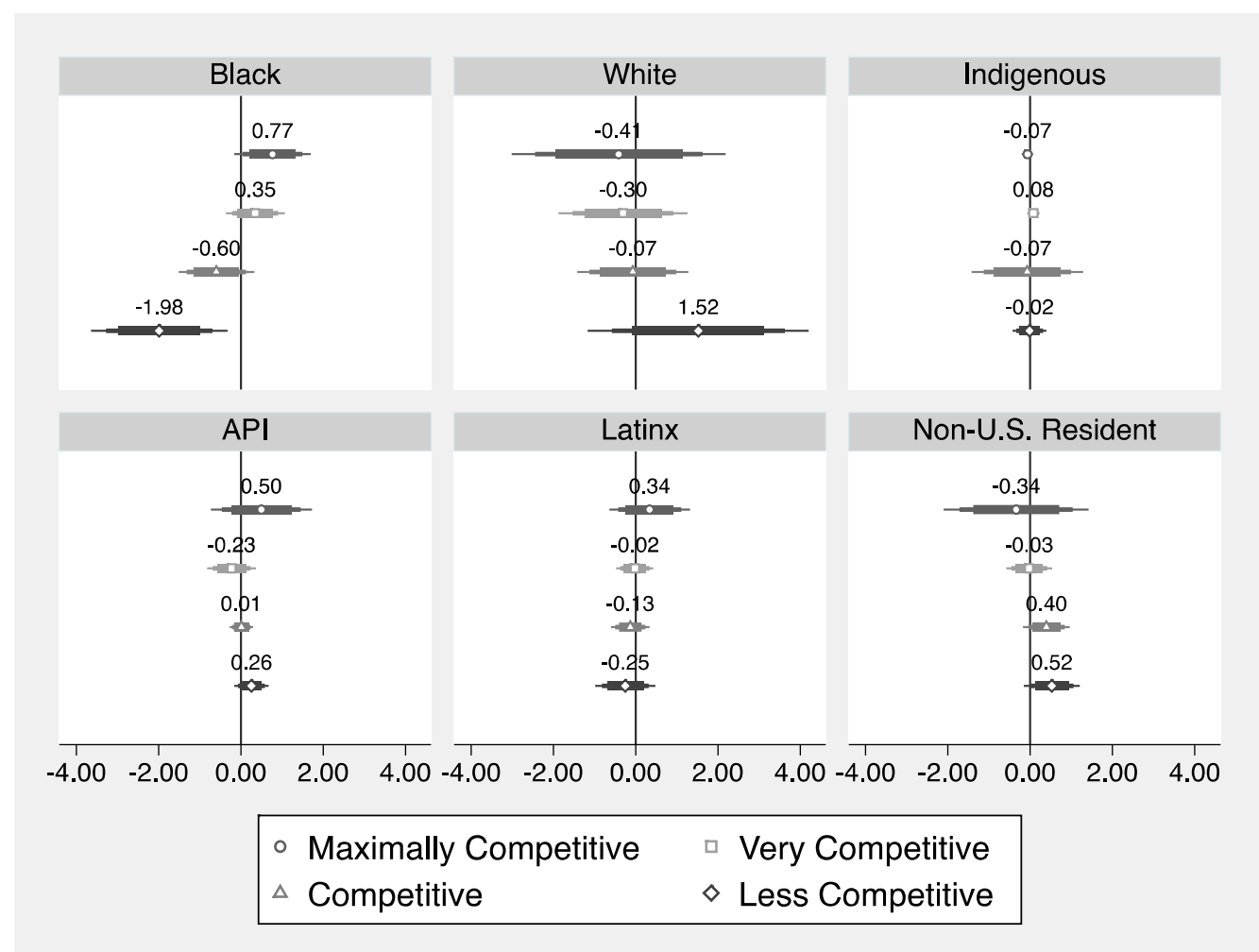

Figure 2. Average Percentage Point Change in First-Year Student Enrollments by Racialized Background Across Selectivity Tiers with 95\%, 99\%, and 99.9\% Confidence Intervals in Years the Institution Stated Policy Usage and Years it Did Not, 1990-2016 (N=1,127). 